\title{
EXPLORING ENTREPRENEURSHIP EDUCATION IN THE PRIVATE HIGHER EDUCATION INSTITUTIONS (HEIS) IN SOUTH AFRICA (SA)
}

\author{
Robert Walter Dumisani Zondo ${ }^{1}$
}

\begin{abstract}
The role of educators in education is indispensable. Hence, students continuously search for a business education that can equip them with the necessary entrepreneurial knowledge and skills to succeed in running businesses. Consequently, this study evaluates the perception of Academic Managers in the private Higher Education Institutions (HEI) of South Africa (SA) on the significance of entrepreneurship education. It explores the reasons for offering such an education in the private HEIs in SA. There were 78 private Higher Education Institutions (HEIs) in SA that were identified for participation in this study. These institutions are registered in terms section 54 (1) (c) of the South African Act (SAQA, 2012). For the study to achieve its objectives, the South African Qualification Authority (SAQA) provided a sample frame of all the private HEIs in SA. From the 78 HEIs identified, 22 offered the pastoral courses and were excluded from the study. As a result, a target population of 56 HEIs participated in the study. This research has two objectives. That is, examining the perception of Academic Managers on entrepreneurship education, and the reasons for offering such education in the private HEIs in SA.

This study uncovers the need for entrepreneurship education in private HEIs of SA. The results present the value of entrepreneurship education as a practice that develops students into cross functional innovative thinkers. It provides valuable data relating to the significance of entrepreneurship education for developing students into business minded individuals.
\end{abstract}

JEL Classification Number: L26; DOI: http://dx.doi.org/10.12955/cbup.v5.977

Keywords - entrepreneurship education, entrepreneurs, opportunities, skills, students

\section{Introduction}

It has been noted that a significant number of entrepreneurship courses have been introduced worldwide as a result of an emergence of entrepreneurship as an academic field. In SA, the trend is exacerbated by the inevitably limited job opportunities where one must compete to secure a job (Nicholaides, 2011). Based on the South African population of 54.9 million, the total number of unemployed people (as in March 2016) was 5.6 million and the not economically active population was 15.05 million (Trading Economics, 2016). Hence, many graduates are unable to get a job upon graduation. Therefore, students continuously search for a business education that can equip them with the necessary entrepreneurial knowledge and skills to succeed in running businesses or to create a job from seizing existing entrepreneurial opportunities (Henry, 2003). As a reaction to such the situation, there has been a growing diversity in the courses offered by the HEI in terms of content and depth (Matlay, 2008). An assessment of the trend reveals that most entrepreneurship courses were offered in business schools but now there is a growing trend of offering them in non-business schools (Gerba, 2012) and such courses are included in the curriculum for teachers (European Commission (EU), 2011). This study aims to determine the perception of Academic Managers on the need for entrepreneurship education in the private HEIs of SA. Generally, entrepreneurship education is needed to address a growing range of contemporary socio-economic and political challenges (Henry, Hill and Litch, 2005) and is therefore relevant for students in all disciplines. Studies on entrepreneurship education have focused on progress in entrepreneurship education (Vesper and Gartner, 1998), the status of entrepreneurship being taught to business students in the UK and USA, respectively (McKeown, Mullman and Sursani, 2006; Solomon, 2007), indicating the diversity of courses in terms of content and methods. Studies in the African context, including those by Co and Mitchell (2006), Kabongo and Okpara (2010) and Gerba (2012) show that entrepreneurship education in Africa is at the development stage and is offered in business schools, and with a few initiatives in non-business courses. Consequently, this research aims to evaluate the significance of entrepreneurship education in the private HEIs of SA. It seeks to determine if entrepreneurship education can positively motivate students towards an entrepreneurial career choice. Furthermore, it establishes the reasons for offering entrepreneurship education in private HEIs in SA.

\section{Attitude towards Entrepreneurship Education}

Entrepreneurship is a process that happens over a period of time, and its first phase is an entrepreneurial attitude (Asenjo and Barberá, 2013). This attitude is the result of a way of thinking and

\footnotetext{
${ }^{1}$ Durban University of Technology (DUT), Faculty of Management Sciences, Durban, South Africa. E-mail: dumisaniz@dut.ac.za
} 
behaving (personality), together with external variables (situational and social) and these form the basis of models to predict entrepreneurial behavior (Krueger, Reilly and Carsrud, 2000). In recent years, curiosity on the subject has given rise to a rapid growth in research on the introduction of business creation as a specific area of study, as well as the concern that entrepreneurial competence be taught systematically on degree courses, influencing the entrepreneurial attitude of university students (Sánchez, 2011; Fenton and Barry, 2014; Hattab, 2014). As a result, this study examines the attitude of Academic Managers in private HEIs on the influence of entrepreneurship education in SA.

The concept of entrepreneurship in education is not solely established in the academia partially because of the variety of research paradigms applied to it that resisted a clear definition (Davidsson, 2004). The interest of this study lies in entrepreneurship as a mindset and is understood to be a fundamental human feature. It is an aptitude that can be developed by anyone (Senges, 2007). Thus, this paper explores if entrepreneurship education can positively motivate students towards an entrepreneurial career choice. Whilst entrepreneurship is an intrinsically motivated practice (Senges, 2007), and entrepreneurship education is a breed of innovative system whose characteristics and activities leads to transformation of the education system; this study examines the significance of such education.

\section{SA's perspective on Higher Education discourse in Entrepreneurship}

It is apparent that the apartheid economic dispensation in SA provided higher education offerings which served the then needs of the industry well, in that they made available a workforce that would be trapped, in a comfort zone, working for a 'boss' (Nicholaides, 2011). The offshoot of such education was to instill within future university students the notion that one should graduate and then seek employment in large corporations or other such formal sector settings rather than opt for something innovative and creative as a work option. Today, SMMEs in SA are accounting for a sizeable chunk of the economic activity (Nicholaides, 2011). However, education is seen as one of the most significant barriers to entrepreneurial activity (Nieman and Nieuwenhuizen, 2014). The result is that, HEIs are increasingly obliged to redefine their role in the SA economy. The primary function of HEIs should thus seek to instill a greater entrepreneurial character among students. HEIs should strive to carefully consider local development needs and support the promotion of entrepreneurial education initiatives, and this should not only be at the tertiary level but as early as the primary school level. This research attempts to establish the perception of Academic Managers in private HEIs if entrepreneurship education should be taught at both school and Higher Education levels. The role of Higher Education is clearly to meet the socio-economic needs of the country whilst safeguarding social justice and democratic values. In addition, HEIs have an important role to play in regional innovation systems and, in what are termed as, the learning areas (Morgan, 1997). Training and development programmes should include views on and encourage entrepreneurship (Nieman and Nieuwenhuizen, 2014). More faculties are required to offer entrepreneurship as a course or at least make it a greater part of existing courses where it does indeed exist (Nicholaides, 2011).

The relationship between university education in general and entrepreneurship in specific, is not so strong and contested (Nabi and Liňán, 2011). Most of these studies have been carried out in developed countries. Few studies have been done on developing countries and these include studies by Jones, Jones, Packham and Miller (2008); Schwalb, Grosse and Simpson (1988), and Wu and Wu (2008). These studies have a common focus on analysing the role of higher education in helping develop new entrepreneurs. However, attempts to promote and implement entrepreneurship education in universities and other HEIs in developing countries have been considerable delayed, in comparison to developed countries. Consequently, SA needs to revamp its human capital strategies if it is to begin to meet the challenges of the global marketplace (Nicholaides, 2011). An effective investment in national higher education initiatives concerning entrepreneurship which will meet the needs of the population, will underpin the international standing of SA's higher education institutions. Only by recognising the great value and importance of entrepreneurship, and by expanding education about it, can SA hope to obtain a pre-eminent position in the world of education and become truly competitive economically (Nicholaides, 2011).

\section{Methodology}

The target population for this study is 78 private HEIs that were registered by the Department of Higher Education of SA. Twenty two private HEIs that focus on pastoral courses were excluded from 
the study. As a result, only 56 private HEIs participated in the study. Recruitment of respondents was undertaken with the aim of ensuring that all the 56 private HEIs participate in the study. As a result, the questionnaires were forwarded to the Academic Managers who represented their institutions in this study through electronic mail. Similarly, the completed questionnaires were sent back to the author via electronic mail. Forty one questionnaires were returned representing a 73.2 per cent response rate, which is considered high compared with the norm for survey responses (Baruch and Holtom, 2008). The main reason for this high response rate was due to the invitation letters sent to all the private HEIs and consistently following up on the questionnaires through telephone calls. The data collected were analyzed using the Statistical Package for the Social Sciences (SPSS) version 22.0. The descriptive statistics were used to analyze the study objectives.

\section{Findings}

\section{Perception of Academic Managers on entrepreneurship education in SA}

The following Table 1 shows results on the perceptions of Academic Managers in entrepreneurship education in the private HEIs in SA.

\begin{tabular}{|l|c|}
\hline \multicolumn{1}{|c|}{ Table 1: Perception of Academic Managers on entrepreneurship education in SA } \\
\hline \multicolumn{1}{|c|}{ Perception on entrepreneurship education in private HEIs in SA } & $\begin{array}{c}\text { Percentage response } \\
\text { accepting this perception }\end{array}$ \\
\hline Lack of skills is the biggest barrier to entrepreneurial success & 62.5 \\
\hline $\begin{array}{l}\text { Entrepreneurship education inspires individual students to become } \\
\text { entrepreneurs }\end{array}$ & 40.0 \\
\hline $\begin{array}{l}\text { Students with higher level of education tend to have higher entrepreneurial } \\
\text { intentions }\end{array}$ & 90.0 \\
\hline $\begin{array}{l}\text { Entrepreneurship should be taught at both school and higher education } \\
\text { levels }\end{array}$ & 45.0 \\
\hline Risk-taking propensity on business interacts with education & 90.0 \\
\hline Entrepreneurship education inspire students to be innovative & 80.0 \\
\hline $\begin{array}{l}\text { Entrepreneurial education can positively motivate students towards an } \\
\text { entrepreneurial career choice }\end{array}$ & \\
\hline $\begin{array}{l}\text { Entrepreneurship education is suitable to those individuals with high self- } \\
\text { efficacy }\end{array}$ & \\
\hline Source: Author & 75.0 \\
\hline
\end{tabular}

The Academic Managers in private HEIs strongly believe in entrepreneurship education for SA. Critical factors as presented in Table 1 include issues relating to: entrepreneurship should be taught at both school and higher education levels; entrepreneurship education inspires students to be innovative; and entrepreneurial education can positively motivate students towards an entrepreneurial career choice. These factors have bigger percentage ranges from 80 to 90 per cent. Academic Managers have also indicated that: the lack of skills is the biggest barrier to entrepreneurial success; entrepreneurship education inspires individual students to become entrepreneurs, and entrepreneurship education is suitable to those individuals with high self-efficacy.

\section{Reasons for offering entrepreneurship education in private HEIs in SA}

The following Table 2 presents results relating to the reasons for offering entrepreneurship education in the private HEIs in SA.

Table 2 provided high percentage response rates from Academic Managers in private HEIs on the reasons to offer entrepreneurship education in SA. The highest reasons that range from 80 to 95.5 percent include: to help reduce poverty; to enhance innate entrepreneurial qualities in students; to assist students exploit business opportunities; to engage students in business start-ups; to develop entrepreneurial culture among young people; to promote innovative thinking; and to contribute to job creation. 


\begin{tabular}{|l|c|}
\hline \multicolumn{1}{|c|}{ Table 2: Reasons for offering entrepreneurship education in private HEIs in SA } \\
\hline To promote innovative thinking & $\begin{array}{c}\text { Percentage response accepting the } \\
\text { reasons }\end{array}$ \\
\hline To assist students exploit business opportunities & 92.5 \\
\hline To inspire students to become entrepreneurs & 87.5 \\
\hline To enhance the innate entrepreneurial qualities in students & 77.5 \\
\hline To develop entrepreneurial culture among young people & 82.5 \\
\hline To contribute to job creation & 90.0 \\
\hline To engage students on business start-up & 95.0 \\
\hline To help reduce poverty & 87.5 \\
\hline Source: Author & 80.0 \\
\hline
\end{tabular}

\section{Conclusion}

This study began by reviewing the global aspect of entrepreneurship education. Minimum research has been carried out on the significance of entrepreneurship education in the private HEIs in SA. Hence, the study examines its significance. Entrepreneurship education gives students a new way of looking at the world, irrespective of whether or not they opt to start or develop their own enterprises. This paradigm should continue to receive increased attention in SA and be vigorously researched. For entrepreneurship to be successful, entrepreneurship education is paramount. The HEIs in SA should provide extra entrepreneurial capacity and this should be especially aimed at creating intention and aspiration in students towards entrepreneurship (Chenube, Saidu, Omumu and Omomoyesan, 2011). Students with high intentions in entrepreneurship will ultimately be more successful (Hisrich, Peters and Shepherd, 2008) and be able to employ others, thus alleviating the huge levels of unemployment in the South African society.

Therefore, students must be taught to identify opportunities in the marketplace and assisted to innovate and create something different in establishing a new venture (Nieman and Nieuwenhuizen, 2014). Hence, entrepreneurship education should encourage students to think and then to do (Neck and Greene, 2011).

\section{References}

Asenjo, M.P. and Barberá, J.P. (2013). Evaluación del impacto de la educación superior en la iniciativa emprendedora. Historia y Comunicación Social, 18: 377-386.

Baruch, Y. and Holtom, B.C. (2008). Survey response rate levels and trends in organizational research. Human Relations, 61 (8): $1139-1160$.

Chenube, O.O., Saidu, R.F., Omumu, F.C. and Omomoyesan, M.B. (2011). Assessing the entrepreneurial inclination of university students in Delta State. IFE Psychology, 19 (2).

Co, M.J. and Mitchell, B. (2006). Entrepreneurship education in South Africa: a nationwide

Survey. Education+Training, 48 (5): 348-359.

Davidsson, P. (2004). Researching entrepreneurship, Boston: Springer.

European Commission (EU). (2011). Entrepreneurship education: enabling teachers as a critical success factor: a report on teacher education and training. Brussels, available at: http://ec.europa.eu/enterprise/policies/sme/promotingentrepreneurship/files/education/ teacher education for entrepreneurship final report en.pdf (accessed 15 February 2016).

Fenton, M. and Barry, A. (2014). Breathing space - graduate entrepreneurs perspectives of entrepreneurship education in higher education. Education+Training, 56 (8/9): 733-744.

Gerba, D.T. (2012). The context of entrepreneurship education in Ethiopian universities. Management Research Review, 35 (3/4): 225-244.

Hattab, H.W. (2014). Impact of entrepreneurship education on entrepreneurial intentions of university students in Egypt. Journal of Entrepreneurship, 23 (1): 1-18.

Henry, B. (2003), Entrepreneurship education in Kenya: A reality or plodding on? The First International Entrepreneurship Conference, 23-24 April Kenya.

Henry, C., Hill, F. and Leitch, C. (2005). Entrepreneurship education and training: can entrepreneurship be taught? Part I. Education+Training, 47 (2): 98-111.

Hisrich, R. D., Peters, M.P. and Shepherd, D. (2008). Entrepreneurship. NY, USA, McGraw-Hill Irwin. 
Jones, P., Jones, A., Packham, G. and Miller, C. (2008). Student attitudes towards enterprise education in Poland: a positive impact. Education + Training, 50 (7): 597-614.

Kabongo, J.D. and Okpara, J.O. (2010). Entrepreneurship education in sub-Saharan African universities. International Journal of Entrepreneurial Behaviour and Research, 16 (4): 296-308.

Krueger, N., Reilly, M.D. and Carsrud, A.L. (2000). Competing models of entrepreneurial

Intentions. Journal of Business Venturing, 15: 411-432.

Matlay, H. (2008). The impact of entrepreneurship education on entrepreneurial outcomes. Journal of Small Business and Enterprise Development, 15 (2): 382-396.

Morgan K. (1997). The Learning Region: Institutions, Innovation and Regional Renewal. Regional Studies, Vol. 31.

McKeown, J., Millman, C., Sursani, S.R., Smith, K. and Martin, L.M. (2006). Graduate entrepreneurship education in the United Kingdom. Education+Training, 48 (8/9): 597-613.

Nabi, G. and Liňán, F. (2011). Graduate entrepreneurship in the developing world: intentions, education and development. Emerald Group publishing, 53 (5): 325-334.

Nieman, G. and Nieuwenhuizen C. (2014). Entrepreneurship: A South African Perspective. Pretoria: Van Schaik.

Nicholaides, A. (2011). Entrepreneurship- the role of Higher Education in South Africa. International Research Journal, 2 (4): 1043-1050.

Neck, H.M. and Green, P.G. (2011). Entrepreneurship Education: Known Worlds and New Frontiers. Journal of Small Business Management, 49 (1): 55-70.

Sánchez, J.C. (2011). University training for entrepreneurial competencies: its impact on intention of venture creation. International Entrepreneurship Management, 7: 239-254.

Senges, M. (2007). Knowledge Entrepreneurship in Universities: Practice and Strategy in the case of Internet Based Appropriation. Barcelona: Universitat Oberta de Catanlunya.

Solomon, G. (2007). An examination of entrepreneurship education in the United States. Journal of Small Business and Enterprise Development, 14 (2): 168-182.

South African Qualification Authority. (2010). Skills Development Act 97 of 1998, section 54 (1) (c).

Schwalb, M.M., and Grosse, R. and Simpson, E.R. (1988). Developing entrepreneurs in developing countries - The PEG Programme in Peru. Journal of Management Development, 7 (4): 31-40.

Trading Economics. (2016), South African Unemployment Rate. Retrieved from: http://www.tradingeconomics.com (accessed 9 July 2016).

Vesper, K. and Gartner, W. (1998). University Entrepreneurship Programmes Worldwide, University of South Carolina, Los Angeles, CA.

Wu, S. and Wu, L. (2008). The impact of higher education on entrepreneurial intentions of university students in China. Journal of Small Business Development, 15 (4): 752-774. 